\title{
A Provincial Assembly during the League
}

\section{Author(s): Maurice Wilkinson}

Source: Transactions of the Royal Historical Society, Vol. 9 (1915), pp. 65-76

Published by: Cambridge University Press on behalf of the Royal Historical Society Stable URL: http://www.jstor.org/stable/3678294

Accessed: 27-06-2016 02:33 UTC

Your use of the JSTOR archive indicates your acceptance of the Terms \& Conditions of Use, available at

http://about.jstor.org/terms

JSTOR is a not-for-profit service that helps scholars, researchers, and students discover, use, and build upon a wide range of content in a trusted digital archive. We use information technology and tools to increase productivity and facilitate new forms of scholarship. For more information about JSTOR, please contact support@jstor.org.

Cambridge University Press, Royal Historical Society are collaborating with JSTOR to digitize, preserve and extend access to Transactions of the Royal Historical Society 


\section{A PROVINCIAL ASSEMBLY DURING THE LEAGUE 1}

By MAURICE WILKINSON, M.A., F.R.Hist.S.

\section{Read December Io, I9I4}

BURGUNDY as a province was devoted to the League, but not in the most fanatical sense. The reasons for its Leaguer sympathies were numerous: its catholicity-the number of Huguenots, though recently proved to have been larger than at one time supposed, was always small as compared with south-west France-the proximity of the Lorraine influence, the nearness of Spain, and above all the souvenir of the fame of the province in the days of the Sovereign Dukes. The provinces in which the royal power had been most recently imposed were usually against the central government-either leaguer or protestant. Paris, no doubt, seems to contradict this view, but all capitals were more fervently Leaguer than the rest of their provinces, and Paris, as the most populous and unquiet city of France, was simply the arch-leaguer. The members of the parlement and the royal officials who were averse to the league early withdrew from Dijon, and Flavigny in the Auxois became the obvious place for a Royalist gathering. In fact, every other place of any size was, at that stage, Leaguer, and Flavigny had facilities for defence. The formal schism of all the judicial, administrative, and financial machinery followed,

1 The authorities for this paper are the documents to be found at (I) The Préfecture; (2) The Palais de justice; (3) The Hôtel de Ville ; (4) The Library of the town-all at Dijon. I have also consulted M. Gros' Le Parlement et la Ligue en Bourgogne; M. Drouot's Notes sur la Ligue en Bourgogne, and his Affaire La Verne, and the volumes known as Analecta Divionensia. The war has prevented my making this paper as complete as I could have wished.

T.S.-VOL. IX. 
as elsewhere, on Henry III's edict from Tours, March I589, ${ }^{1}$ which suspended the parlements from their functions.

In 1589 the royalist party at Dijon was composed only of the fourth president, Fremyot, ${ }^{2}$ a really distinguished and conscientious man, a few conseillers de parlement, and a few of the noblesse. These rapidly increased, and there was also a small body of men at arms who were very irregularly levied, and still more irregularly paid, by Guillaume de Tavannes, the royal governor. Mayenne had rendered the magistrates of Dijon and the people obedient to the League as early as August I588; after the murder of the Guises, he, in January of the next year, further consolidated his authority.

'Parcequ'il est besoing $\&$ expédient $\&$ nécessaire que chacun des habitants $\&$ aultres demeurent armez pour la confirmation, tant de leurs propres personnes, de tous les gens de bien, que pour le repos d'icelle ville en gñal; à ceste cause ordonnons à tous les sieurs ecclésiastiques d'icelle de se tenir armez dans leurs maisons pour, en cas de nécessité, s'assembler soubz leurs chefz pour obéyr \& faire ce qu'il leur sera commandé par M. de Fervasque, que nous avons laissé pour gouverner \& commander dans lad: ville de Dijon pendant nostre absence.

a Dijon le 27 jour de janvier $1589 .^{3}$
PICCART.
Charles DE LoRRaINe.'

This order gave complete power to the adherents of the house of Lorraine. Odibert and Bretagne, two conseillers de parlement, protested and were imprisoned, and proscription lists were drawn up : all thought of resistance left the minds of the magistrates.

Mayenne's lieutenant, Fervaques, the Count of Grançay, ${ }^{4}$

1 March 27, 1589: Archives du greffe de la cour d'appel, Dijon, B I2086, f. II. April I7, I589: Edict establishing the court at Flavigny, Bibliothèque de Dijon; Fonds Saverot No. 3. The parlements of Bordeaux and Grenoble alone were not transferred.

2 Benigne Fremyot, seigneur de Thôtes; president, r58r; died, r6Ir.

3 Archives Municipales, Dijon, B 457.

- Guillaume de Hautemer. The party of Mayenne all through gained great strength from the devotion of Franchesse, the captain of the Castle of Dijon. 
on March 23, came into the palais and informed the court that he required them to swear the Articles of Union, which had just come from Paris.

These articles were ordered by Fervaques to be signed without any addition or diminution. Two of these are worth reproducing here, for they are most significant. ${ }^{1}$

' Jurons de conserver en son ancienne splendeur la cour de Parlement \& la chambre des Comptes en ceste ville selon la convention faitte entre les prédécesseurs Roys \& les Estatz; sans permettre qu'elles soyent transférées ailleurs au préjudice d'icelles, comme aussi tous aultres sièges éstablis d'ancienneté ès villes de ceste province qui entreront en la Ste Union.'

' Jurons encores de nous rendre obéissans aux commandements de $\mathrm{M}^{\mathrm{r}}$ le duc du Maine \&, en son absence, à M. de Fervaques desquels nous ne nous separerons jamais, quelque mandement qui puisse avenir de qui ce soit.'

This was too much for Bretagne, a conseiller, who proposed an amendment 'sous le nom \& authorité du Roy' : this was rejected and the articles as sworn were to all intents and purposes a repudiation of the King of France.

The first president Brulart ${ }^{2}$ swore 'entre les mains ' of Bernard Desbarres ${ }^{3}$ second president.

The other presidents, Desbarres, de Crespy, ${ }^{4}$ de Montholon, ${ }^{5}$ and most of the conseillers, but not the eminent Jeannin ${ }^{6}$ although a Leaguer, likewise took the oath. Fervaques had more trouble with the Chambre des Comptes, but again by his personal influence, and we may guess also

1 From January Fervaques had often seated himself at the bureau of the palais and harangued the parlement. This extract and the matter in full are taken from the Journal du Palais, 'Extrait des registres du P. Bib. Dijon Fonds de Juigné.' I6II.

2 Denis Brulart, formerly conseiller at the parlement of Paris; died,

3 Desbarres was mayor of Dijon, $\mathbf{r}_{574}$, and became canon of Langres ; died, I599.

- Claude de Crespy, fifth president.

S Nicolas de Montholon, sixth president : president, 1585; died, r603.

- Pierre Jeannin was now third president; born at Autun, I540; resisted the idea of a massacre at Dijon in August 1572; resigned office, 1602; died, 1623 . 
by threats, finally won over the president and the maitrer des comptes : indeed it is recorded in the register that certain of them swore only to save their goods. Democratic as the League was, or at any rate became, in the large towns, its methods are made clear by the above incidents: and the large numbers of citizens who hated the democratic control, but dared not move, is made certain by the enthusiasm with which Henry IV was finally welcomed by the former Leaguer towns. The new Royalist court at Flavigny only consisted of seven : an edict was consequently necessary to give their arrêts sovereign authority. Early in April fresh adherents came in : the maitre des requêtes Bossuet, conseiller Lagrange, the procureur à la cour, and the auditeurs des comptes arrived at Flavigny. ${ }^{1}$ The conseillers de parlement Colard, Saumaise, Millet, La Reynie, and procureur général Picardet ${ }^{2}$ soon followed. These all, of course, had to escape from Dijon on various pretexts and under promise of return : their property and, in some cases, their wives suffered when their destination was realised. ${ }^{3}$ The avocat général Maillard, and procureurs Mignard and Turreau, with the conseillers Molleron and Tisserand arrived in May, and finally Briet and Milletot in the autumn. ${ }^{4}$ The number of magistrates at Flavigny was now twenty-nine. The schism was now complete: two parlements-shortly two estates-two sets of financial machinery were claiming equal or rather supreme authority in the province. An interesting constitutional question from our point of view : legal tradition, continuity, an appearance at any rate of popular support on the one side; on the other, the royal authority, such as it was, a few nobles, several paid crown officials. Yet the Holy Union stood for foreign power in France, for clericalism, for the very disintegration of the country: and the royal power, however weak and

1 Archives Municipales, Dijon, B 226, f. 236.

2 Hugues Picardet, sieur de Belleveure, was born at Mirebeau, 1560 ; died, I641. Arch. Mun., Dijon, B 226, f. 229.

3 Arch. Mun., Dijon, B 226, f. 20 r.

4 Arch. Mun., Dijon, B 227, f. 77, August; id., f. Iro, October. 
unsatisfactory the then wielder of it, stood for national freedom and unity. Before long a town of more suitable size became available for the purposes of a royalist centre, Semur en Auxois, and Tavannes, to whom the necessity of raising the usual taxes on that part of the province over which he exercised some power became pressing, summoned the estates to meet at Semur in May I590. ${ }^{1}$

Before considering these estates it may be useful to outline the various administrative, electoral, and financial divisions of the province and to remember their significance in the sixteenth century; for the names, though similar, carried a different meaning in the two following centuries. Dijon, the seat of the parlement, had also a chambre des comptes, cour des aides, and was a siège présidial. They varied very much in number, and since Henry II's reign had largely replaced the bailliages. Theśe présidiaux were normally Châtillon sur Seine, Semur, Autun, Chalon sur Saône, Macon, Charolles. Some confusion was caused by an arrêt of the royalist parlement, May $\mathrm{I}_{5}, \mathrm{I}_{5} 89$, transferring some of these seats: thus Chalon was transferred to Louhans, Châtillon to Aisey le Duc, Dijon to Is sur Tille, and then to St. Jean de Losne, Autun to Saulieu, Charolles to Bourbon Lancy. ${ }^{2}$ The whole financial area under the control of the estates was the Généralité of Dijon. The chef lieux d'élections were some eighteen in number and hardly worth numerating, but those of Beaune and Nuits were transferred to St. Jean de Losne, and Avallon to Montréal. ${ }^{3}$

Auxonne across the Saône, in theory in the ressort of Dijon, at this date enjoyed a complicated and unsatisfactory system of its own. The Saône roughly divided elsewhere Burgundy from Spanish Franche Comté. The Monnaie was transferred from Dijon to Semur, and the Bureau de la Traite Foraine to St. Jean de Losne. ${ }^{4}$ The

1 'Procès verbal of the royalist estates of Semur,'Arch. Dép. Préfecture, Dijon, C 3070,4 .

2 Registres du parlement, Bib. Dijon; Fonds Saverot, Tom. iii.

3 Idem.

- Edict, May 12, 1589; Fonds Saverot, Tom. iii. 
Chambre des Comptes was at Semur and the relationships of the magistrates with the élus royalistes were very intimate owing to the necessities of the times. Frequent conferences were necessary between them; and the élus were constantly claiming the support of the parlement to sanction their decisions by an arrêt. This close union of parlement, états, chambre des comptes, went far to strengthen the position of the little royalist centre. Such union in normal times would have been remarkable, and might have acquired for provincial governments an authority to which they never attained.

At these estates of Tavannes the clergy were represented by very few ecclesiastics, and only one of importance, d'Escars, bishop of Langres; the noblesse by forty-five gentilshommes, chiefly from the Auxois, the best known being de Ragny, ${ }^{1}$ Marcilly de Cypierre, ${ }^{2}$ the Marquis de Nesle, Choiseul de Chevigny, and the two Chantals ${ }^{3}$; the tiers by nineteen deputies. Their names, in themselves of no interest, are of value in showing what sort of popular representation was attracted to Semur.

The leader of the tiers was noble François Fyot, 'qui se dit maire de Dijon combien il ne fut jamais élu ni entré dans lad: ville.' 4

$\mathrm{M}^{\mathrm{e}}$ Benigne Petit, procureur général du roy.

Ospiard, con ${ }^{\text {ser }}$ au ball: d'Ostun, ${ }^{5}$ élu par les refugiés de lad: ville.

Sirmot, maire de la ville de Semur.

Nicolle, echevin deputé d'icelle.

J. B. Chevalant, con ${ }^{\text {er }}$ au baill: de Nuys, élu par les refugiés de lad: ville.

1 François de la Madeleine, afterwards governor of the Nivernais; born, I543; died, I625.

2 Humbert de Marcilly, cousin of above. He was the son of the tutor of Charles XI, governor of the Auxerrois and Knight of the St. Esprit, and held many titles.

3 For all these men see Beaune and d'Arbaumont, La Noblesse de Bouxgogne aux états, also register $\mathrm{C}_{3070}$, Arch. Dép., Dijon.

- Arch. Dép., Dijon, C 3070, 4.

5 Autun. 
ROUE POUR SÇAVOIR LE TOUR DES EVESQUES ABBÉS ET DOYENS QUI SONT ESLEUS EN L'ASSEMBLÉE GÑALLE DES GENS DES TROIS ESTATZ DE BOURGOGNE QUI SE FAICT DE TROIS EN TROIS ANS LE TOUR DES NEUFV VILlES DUD: DUCHÉ AVEC LE VIC: MAJ: DE DIJON QUI DOIBVENT ASSISTER AVEC L'ESLEU DES NOBLES LES GENS DES COMPTES ET ESLEU POUR LE ROY À TOUS FEU ET IMPOSTS QUI SE FONT SUR LES SUBIECTZ DUDICT ET DEPARTEMENS DICEULX.

(Archives Dép. Dijon, r564)
C 3070.

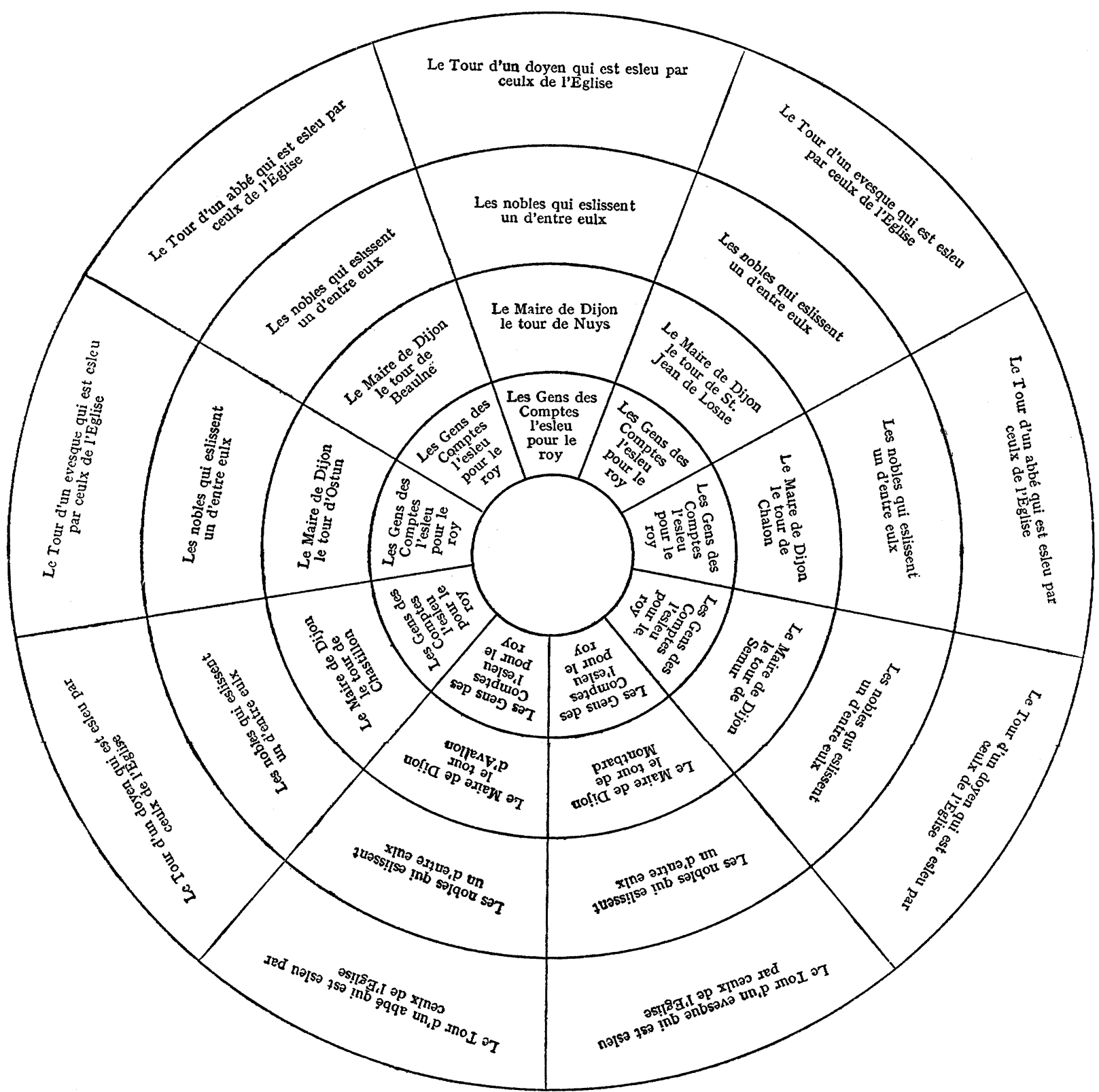


Audin, ville de Montbard.

Noble G. de Filzjean, $\mathrm{s}^{\mathrm{r}}$ de Chaolnes.

Le $\mathrm{Con}^{\text {ser }} \mathrm{du}$ roy au baill: d'Avallon.

Notaire royal dep: de lad: ville.

Procureur du roy au baill: de Chastillon.

Lieut. criminel au présidial d'Arnay le Duc.

Mornay, procureur baill: de Seurre.

Procureur syndic. de Flavigny.

Commissaire de l'Artillerie.

Garde des vivres. (This man had been named by Tavannes to regulate market prices in the Auxois.)

'Toutes les aultres villes n'ont aulcun deputé en lad: assemblée.'

This hardly seems a representative body, and it was not; but the presence of royal officials was not more marked than in normal estates. ${ }^{1}$ The noblesse were fairly well represented, but the clergy, who were naturally Leaguer, and the tiers, who were after all only a section of the people, and that the Leaguer town element, were mainly absent.

\section{The Estates of I590.}

The opening harangues were given, as usual on such occasions, at great length by Guillaume de Tavannes and Fremyot. The chief points were :-

I. The assembly recognises Henry IV as sole lawful King, and prays him to confirm the old privileges of the province, to preserve the Church, and to provide for the government of the province.

2. To deprive all royal officials who remain in the rebel towns. To summon the magnates for the last time to

1 See the 'wheel' for the normal manner of representation at the estates. This was drawn by some clerk about thirty years earlier, but the method of representation had not altered. Burgundy, besides the advantages of a Pays d'Etat, had also certain exceptional privileges in the matter of taxation. 
recognise his authority under penalty of rebellion and lèse majesté.

3. To confirm the edict of Henry III which annexed Macon, Auxerre, Bar sur Seine, to the ressort of the parlement.

4. To render the magistrates of rebel towns responsible for the royal deniers (i.e. by means of confiscation), also to make them responsible for the seizure of loyal men's goods.

5. To constitute a proper chambre des comptes.

On these points the three cahiers are agreed.

(a) The noblesse invite Tavannes to suppress futile garrisons and dismantle all fortresses built by 'particuliers n'ayant aulcun fief ni jurisdiction.' The tiers assent; the clergy make no comment.

(b) The noblesse require Tavannes to appoint none but capable and devoted men to his council. The clergy and tiers are not wholly favourable ; probably they scent danger from the possible appointment of Huguenots. The noblesse as such had always far less natural antipathy to the Reformation movement than had the tiers, and obviously the clergy.

(c) Ecclesiastics to recommend obedience to the King ; this by the noblesse and tiers.

(d) The cahiers agree in praying Tavannes to keep open and assure as far as possible the 'voies de commerce.' 'Business as usual' was as popular a cry amongst the trading classes of the sixteenth century as it has been to-day; and it is curious to notice how often commercial interests outweighed the wishes of devoted partisans whether Royalist or Leaguer.

The money is next voted, and now comes some considerable dissension. The clergy at all times have an especial aversion to parting from their endowments. They demand 'd'estre deschargés de toute contribution sans exception, afin de n'etre point distrait de leurs fonctions pieuses.' A very ingenious formula! The other estates 
reply ' qu'il ne sera rien innové à ce qui s'est fait du passé.' Tavannes is emphatic on the subject. The clergy protest with vigour. In reality their protest had little meaning because practically all the clergy were Leaguers; and as time went on and the power of the royal governor grew, the time-honoured practice of seizing their temporalities to ensure payment was employed. Finally-

50,000 écus were voted for the King's service; 4000 for the governor, i.e. the Count of Charny ${ }^{1}$ who was however in Mayenne's hands; 2000 for Tavannes;

500 for Fremyot;

IOo for the secretary of state de Gesvres;

Io per month for messengers.

Cothenot, a counseiller, informed the estates that a German lord offered to lend I50,000 écus if the King would guarantee him the mortgage on the comté de Neuchâtel. The estates answered that so far neither their powers nor inclinations extended. ${ }^{2}$

The tiers next presented a petition to the King on the subject of ravages, thefts, and violence committed by the men of St. Sorlin and de Viteaux in the Charollais. The two other orders assented.

The noblesse and the tiers call on the parlement to pursue as rebels those who, since the interdiction of the parlement at Dijon, call themselves élus and pretend to exercise that authority.

The parlement, by its spokesman the Procureur Général Picardet, issued an injunction to the Syndic des Etats to pursue 'ceux qui demeureront dans leurs maisons les bras croisés sans assister le roi de façon que ce soit,' as well as against 'traîtres qui par artifices ont empesché les

1 This is the same governor of Burgundy who saved the province from the St. Bartholomew massacre. His correspondence I have collected for the Huguenot Society, by which it has been published.

2 Some of the loan was finally raised by the Cantons of Zürich, Basel, and Bern, Arch. Dép. Dijon, C 3070, f. 6r. The Archives Mun. also contain many contracts with the Catholic Swiss in the Leaguer interest. 
gens de bien d'agir pour le service du roy.' It was also decided that none who had any dealings with the League were eligible for office unless they formally gave in their obedience to the King, to the parlement, and to the governor. The question of helping Marshal d'Aumont in warlike operations against the Spaniards was considered. The élus invited de Crespy to advance 3000 écus for Aumont's expedition. He replied, probably truly, that he had no money. The tiers protested against any idea of the expense being thrown on the généralité, and a loan amongst persons of substance was decided on. Fyot who had gone to an assembly of élus at Flavigny had been captured by Leaguers and put up to 2000 écus ransom. This sum was ordered to be raised.

Procureur Général Picardet who had deserved well of the national cause was ennobled.

Finally the letters patent were produced which named Tavannes Lieutenant General of Burgundy during the forced absence of Charny.

To turn to the rival organisation of the League. At its strongest the League had about forty of the parlement: the first President Bruslart, the second Des Barres, the third Jeannin, and the famous conseiller Pierre Bernard are the only members who need be mentioned; of these several afterwards fled and turned up, as we have seen, at Flavigny.

The Leaguer Estates held in October 1590 and convoked by Fervaques were attended by numerous deputies ${ }^{1}$ : practically the whole of the higher clergy; for the tiers, all the towns and élections, except Semur and Flavigny, mainly represented by legal officials; for the noblesse, comparatively few of little mark, except such names as

1 All Leaguer assemblies are difficult to describe in detail for the reason that the restored parlement at Dijon, by an arrêt of July I595, ordered all registers of the pretended authorities of the League to be rayés et biffés. A few only biffés are amongst the Arch. Dép., but more may be gleaned from the Arch. Mun. In many cases registers may be seen from which the pages have been torn out. 
de Lux, ${ }^{1}$ de Vitteaux, ${ }^{2}$ Sennecy, ${ }^{3}$ Montmoyen, ${ }^{4}$ de Thenissey. Of these Lux and Vitteaux were conspicuously scheming and self-seeking Leaguers; the next two were devoted adherents of the house of Lorraine ; and the last was little better than a brigand. The parlement and estates soon became of less and less authority: the Conseil d'Etat de la Ligue was the real power in the province, and the parlement was often engaged in trying to prevent the excessive harshness of the élus towards the poor, and generally to regularise the finances. Mayenne himself was disposed to deal kindly with the poor peasant defaulters; but power was slipping from the relatively decent Leaguer chiefs and, as in Paris, was falling into the hands of a section of the municipality and the lower classes. We must seek our information for the nominal acts of Leaguer estates and parlement, not in the archives of the palais, but in those of the Chambre de la Ville. The municipality, furiously Leaguer, regarded the parlement as very lukewarm and never ceased to do all it could to lessen the magistrates' authority. Their wishes were frequently ignored and the replies to the parlement were always disrespectful and often insolent. One curious act of usurpation by the Chambre de la Ville is worth relating. The municipality summoned its bishop, d'Escars, who was, as we have seen, a Royalist, to name a Vicar General within fifteen days; or failing that the chambre would appoint one without reference to the bishop. D'Escars refused to be bullied, so the town council appointed one of its own members, Claude Péto by name. ${ }^{5}$ Clement VIII gave a bull to confirm these powers. ${ }^{6}$ It is curious to see a

1 Edmond de Malain was nephew of Epinac, archbishop of Lyon; arrested at Blois with the Guises, 1588 .

2 Maurice de Vergy. For the treachery and pillages, even in churches, of these two see the Journal de Breunot.

3 Claude de Baffremont.

- Edmond Regnier, governor of Beaune until its capture by Biron, 1595 .

- Arch. Mun., Dijon, B 228, f. I8I ; La Cuisine, ii. I89.

- Registered in parlement, I592; Arch. du Greffe, B I2085, f. 25. 
pope for political advantages supporting an irregular civil power against a dignitary of the Church. Montholon and Bruslart with growing bitterness had to submit, after a useless wrangle, to this and other humiliations; and their complaints addressed to the Vicomte de Tavannes ${ }^{1}$ passed unnoticed. The credit of the parlement fell more and more, and all real power belonged to the curés, the orders, and the mob. Here at Dijon was being reproduced the situation in Paris: the municipal council had slipped from the control of the parliament and the Council of Union. The clerical democracy of the League was the cause of its immense popularity and its strength up to a certain point, but it sickened the Leaguer nobles; and Mayenne soon loathed in his heart the spirit of anarchy which his brother had conjured up, and possibly might have controlled, but which he himself was wholly incapable of exorcising.

Thus all the elements of final success were on the royal side, and the province in general came round without much difficulty: the capital, as usual, remaining Leaguer to the end. The final rejection of the League was caused by the growing nationalism of the people: the feeling that Spain and the internationalism of the Jesuits were the common enemy; ' pereat societas judaica cum tota gente iberica.' The proximity of Spanish territory to Burgundy soon made this sentiment predominant as the popularity of the Lorrainers waned, for they were hardly French; and Mayenne, however irksome he may have felt it, depended largely on the Spanish goodwill.

The French nation since its making by Louis XI has ever shown an extraordinary sense of nationality when menaced by a danger from without, and a unity known to no other country in the face of the enemy. This admirable feature of the French people is again being amply displayed to-day.

1 Jean de Saulx was brother of Guillaume the royal governor, and both were sons of the marshal. 